\title{
STUDI PENENTUAN TARIF PENUMPANG ANGKUTAN BUS SEDANG (Studi Kasus Trayek Lhokseumawe-Bireuen)
}

\author{
T. M. Ridwan \\ Jurusan Teknik Sipil, Fakultas Teknik, Universitas Malikussaleh \\ Email: ponwan_04@yahoo.com
}

\begin{abstract}
Abstrak
Bus Cendrawasih salah satu bus yang menyediakan jasa angkutan umum penumpang dengan trayek Lhokseumawe-Bireuen dengan jarak tempuh 56 $\mathrm{km}$ setiap trip dan frekuensi pelayanan 3 trip perhari pulang-pergi. Dalam penelitian ini ingin mengetahui seberapa besar tarif angkutan penumpang berdasarkan Biaya Operasi Kendaraan yang ditinjau dari direct cost dan indirect cost. Berdasarkan hasil survey dan analisa data yang dilakukan dalam penelitian ini dapat dinyatakan bahwa Angkutan umum bus CV. Cendrawasih dapat memberikan pelayanan yang relatif baik walaupun jumlah armada yang beroperasi hanya 35 unit. Faktor pembebanan (load factor) ratarata angkutan antar kota sebesar $45 \%$ dengan jumlah rata penumpang per ritnya adalah 13 penumpang. Besarnya biaya operasi kendaraan Biaya langsung sebesar Rp. 2.013,740 /bus-km, Biaya tidak langsung Rp. 18,020 / bus-km. Besarnya biaya operasi kendaraan rata-rata sebesar Rp. 156,289 $/ \mathrm{pnp} / \mathrm{km}$. Besarnya tarif dihitung berdasarkan biaya operasi kendaraan (BOK) dan jumlah penumpang rata-rata/trip sebesar Rp. 8.752,20 /penumpang. Tarif yang telah diberlakukan selama ini adalah sebesar Rp. 10.000,00. Hal ini menunjukkan tarif masih sesuai
\end{abstract}

Kata kunci: Tarif Penumpang, Bus Sedang

\section{Pendahuluan}

Seiring dengan meningkatnya pertumbuhan penduduk dan adanya peningkatan ekonomi menyebabkan jumlah perjalanan yang dilakukan oleh individu-individu semakin meningkat, Meningkatnya kebutuhan transportasi seiiring dengan pengembangan sarana dan prasarana transportasi, kendaraan, jalan, lingkungan dan manusia bersama-sama untuk membentuk sistem lalu lintas. Angkutan antar kota sebagai salah satu jenis dari bentuk transportasi harus dapat memberikan pelayanan yang baik terhadap para pengunanya, baik dari kenyamanan, ketepatan waktu dan biaya yang terjangkau bagi seluruh lapisan masyarakat. Jika hal-hal tersebut dapat terpenuhi maka angkutan antar kota sebagai transportasi massal merupakan transportasi yang ideal bagi masyarakat. Terkait dalam hal ini, tarif angkutan umum yang murah menjadi suatu faktor penentu pilihan penumpang terhadap angkutan umum. Tarif menjadi faktor yang penting dalam mendapatkan pelayanan dan fasilitas yang diberikan oleh karena itu penentuan tarif dan kebijakannya dari suatu angkutan umum merupakan elemen paling penting dalam operasi bus dan mempengaruhi sikap penumpang dalam melakukan perjalanan. Bus Cendrawasih merupakan salah satu bus yang menyediakan jasa angkutan umum penumpang dengan trayek LhokseumaweBireuen dengan jarak tempuh kurang lebih $56 \mathrm{~km}$ setiap trip dan frekuensi pelayanan 3 trip perhari pulang-pergi. Dalam penelitian ini ingin mengetahui sebererapa besar tarif angkutan penumpang berdasarkan Biaya Operasi Kendaraan yang ditinjau dari direct cost dan indirect cost. 


\section{Tinjauan Kepustakaan}

\subsection{Tarif Angkutan Umum}

Menurut Departemen Perhubungan (2002), tarif adalah besarnya biaya yang dikenakan kepada setiap penumpang kendaraan angkutan penumpang umum yang dinyatakan dalam bentuk rupiah. Perhitungan tarif angkutan umum merupakan hasil perkalian antara tarif pokok dan jarak (kilometer) rata-rata satu perjalanan (tarif BEP) dan ditambah $10 \%$ untuk jasa keuntungan perusahaan, rumus yang digunakan adalah sebagai berikut:

$$
\begin{aligned}
& \text { Tarif } \quad=(\text { tarif pokok } x \text { jarak rata-rata })+10 \% \\
& \text { Tarif BEP = tarif pokok } \mathrm{x} \text { jarak rata-rata } \\
& \text { Tarif Pokok }=\frac{\text { total biaya pokok }}{\text { faktor pengisian } x \text { kapasitas kendaraaan }}
\end{aligned}
$$

Faktor muat adalah perbandingan antara kapasitas terjual dengan kapasitas yang tersedia untuk satu perjalanan, Nilai load factor dapat diitung dengan mengunakan rumus:

di mana:

$$
L f=\frac{P_{s g}}{c} \times 100 \%
$$

$$
\begin{array}{ll}
\mathrm{Lf} & =\text { load factor } \\
\mathrm{Psg} & =\text { total jumlah penumpang pada setiap zona (penumpang) } \\
\mathrm{C} & =\text { kapasitas kendaraan (penumpang) }
\end{array}
$$

\subsection{Sistem Penentuan Tarif Angkutan Umum}

Tarif bagi penyedia jasa angkutan (operator) adalah harga dari jasa yang diberikan. Sedangkan bagi pengguna jasa, besarnya tarif merupakan biaya yang harus dibayarkan untuk jasa yang telah dipakinya. Ada tiga cara menentukan sistem penentuan tarif, yaitu:

1. Tarif Berdasarkan Biaya Operasi (cost of service princing), dinyatakan per penumpang-kilometer,

2. Tarif Berdasarkan Nilai Jasa (value of servie princing), besar kecilnya tarif ditentukan nilai yang diberikan pemakai jasa.

3. Tarif Berdasarkan What the traffic will bear, berada antara batas maksimum dan batas minimum. Untuk itu dasar tarif ini adalah berusaha menutupi seluruh biaya variabel dan sebagian biaya tetap.

\subsubsection{Jenis Tarif Angkutan}

Abbas Salim (1993), tarif angkutan adalah suatu daftar yang memuat hargaharga untuk para pemakai jasa angkutan yang di susun secara teratur.

a. Tarif Menurut Trayek, angkutan berdasarkan atas pemanfaatan operasional dari moda transpor yang di operasikan dengan memperhitungkan jarak yang dijalani oleh moda transpor tersebut $(\mathrm{km} / \mathrm{mil})$.

b. Tarif Lokal, adalah tarif yang berlaku dalam satu daerah tertentu misal tarif bis yang berlaku khusus di DKI.

c. Tarif Diferensial, adalah tarif angkutan dimana terdapat perbedaan tinggi tarif menurut jarak, berat muatan, kecepatan atau sifat khusus dari muatan yang diangkut. 
d. Tarif Peti Kemas (Container), adalah tarif yang diberlakukan untuk membawa kotak/box di atas truk berdasarkan ujuran box/kotak yang diangkut (20 feet atau 40 feet) dari asal pengiriman ke tempat tujuan barang (A/T).

\subsubsection{Kebijakan Tarif}

Warpani (2002), menyatakan kebijakan tarif dapat dipandang sebagai kebijakan multisisi, di satu sisi dapat dipandang sebagai alat pengendali lalu lintas, di sisi yang lain dapat berarti alat untuk mendorong masyarakat mengunakan kendaraan umum dan mengurangi pengunaan kendaraan pribadi, dan sisi yang lainnya lagi dapat digunakan untuk mengarahkan perkembangan wilayah dan kota.

\subsection{Penentuan Tarif Angkutan Umum}

Warpani (2002), menyatakan penentuan tarif angkutan biasanya didasarkan atas biaya operasi (penyelengaraan) jasa angkutan yang terdiri atas: biaya tetap, yaitu biaya yang tidak berpengaruh oleh kegiatan pengoperasian kendaraan. Penyedia jasa (pengusaha angkutan) selalu menginginkan pemberlakuan tarif setinggi mungkin dengan maksud mempercepat pengambilan modal, sedangkan penguna jasa (penumpang) selalu menghendaki tarif serendah mungkin. Dalam upaya mempertemukan kedua kepentingan ini, maka tarif jasa angkutan umum tertentu ditentukan oleh pemerintah. Penentuan tarif beberapa macam jasa angkutan diserahkan pada mekanisme pasar, yakni kesepakatan antara penguna jasa dengan penyedia jasa. Dalam masa tertentu, pemerintah dapat menerapkan tarif khusus yakni tambahan biaya yang harus dibayar oleh penumpang

\subsection{Tarif Berdasarkan Biaya Operasi}

Biaya operasi dihitung dalam biaya operasi satuan yang dinyatakan dalam rupiah per ton-km (Rp/ton-km) bagi angkutan barang dan rupiah per penumpang$\mathrm{km}(\mathrm{Rp} / \mathrm{pnp}-\mathrm{km})$ bagi angkutan penumpang. Perhitungan biaya operasi ini dirinci secermat mungkin dengan mempertimbangkan berbagai hal. (Warpani, 2002)

\subsection{Biaya Operasional Kendaraan (BOK)}

Biaya opersional kendaraan adalah biaya yang secara ekonomis terjadi karena dioperasikannya satu kendaraan pada kondisi normal untuk suatu tujuan tertentu. Sesuai Standart Direktorat Jendral Perhubungan Darat RI (2002), Biaya operasi kendaraan dapat dibagi menjadi dua, Biaya Langsung dan Biaya Tidak Langsung.

\subsubsection{Biaya Langsung (Direct Cost)}

Biaya langsung adalah biaya yang langsung dapat dibebankan pada biaya operasi kendaraan atau biaya pokok, yang dapat dibagi lagi menjadi:

1. Biaya Tetap (Fixed Cost), adalah biaya yang tidak berubah walaupun terjadi perubahan pada produksi jasa sampai ketingkat tertentu. Biaya tetap terdiri dari a) Penyusutan Kendaraan, b) Pajak Iuran Kendaraan, c) Pendapatan Awak Bus

2. Biaya Variabel (variable cost), besarnya tergantung pada pengoperasian kendaraan yaitu a) Bahan Bakar Minyak (BBM), b) Ban, c) Service Kecil, d) Service Besar, e) Pemeriksaan Umum (general overhaul), f) Penambahan Oli Mesin, g) Cuci Kendaraan, h) Restribusi Terminal, i) KIR dan j) Asuransi 
Tabel 1 Pedoman Perhitungan Biaya Pokok

\begin{tabular}{|c|c|c|c|c|c|c|c|}
\hline \multirow{3}{*}{ No } & \multirow{3}{*}{ Uraian } & \multirow{3}{*}{ Satuan } & \multicolumn{5}{|c|}{ Angkutan Kota } \\
\hline & & & \multicolumn{2}{|c|}{ Bus Besar } & \multirow{2}{*}{$\begin{array}{c}\text { Bus } \\
\text { Sedang }\end{array}$} & \multirow{2}{*}{$\begin{array}{l}\text { Bus } \\
\text { Kecil }\end{array}$} & \multirow{2}{*}{$\begin{array}{l}\text { Mbl.Penm. } \\
\text { Umum } \\
\text { (MPU) }\end{array}$} \\
\hline & & & $\begin{array}{l}\text { Bus } \\
\text { DD }\end{array}$ & $\begin{array}{l}\text { Bus } \\
\text { SD }\end{array}$ & & & \\
\hline 1 & $\begin{array}{l}\text { Masa penyusutan } \\
\text { kend. }\end{array}$ & Th & 5 & 5 & 5 & 5 & 5 \\
\hline 2 & Jarak tmph rata-rata & $\mathrm{Km} / \mathrm{hr}$ & 250 & 250 & 250 & 250 & 250 \\
\hline 3 & Bahan bakar minyak & $\mathrm{Km} / \mathrm{lt}$ & 2 & $3,6-3$ & 5 & $7,5-9$ & $7,5-9$ \\
\hline 4 & Jarak tmph.ganti ban & $\mathrm{Km}$ & 24.000 & 21.000 & 20.000 & 25.000 & 25.000 \\
\hline 5 & Ratio pengemudi/bus & Org/ken & 1,2 & 1,2 & 1,2 & 1,2 & 1,2 \\
\hline 6 & Ratio kondektur/bus & Org/ken & 1,2 & 1,2 & 1,2 & - & - \\
\hline 7 & $\begin{array}{l}\text { Jrk.tmph.antar } \\
\text { serv.kcl }\end{array}$ & $\mathrm{Km}$ & 5.000 & 5.000 & 4.000 & 4.000 & 4.000 \\
\hline 8 & $\begin{array}{l}\text { Suku cadang/service } \\
\text { bsr }\end{array}$ & $\mathrm{Km}$ & 10.000 & 10.000 & 10.000 & 12.000 & 12.000 \\
\hline 9 & Peng. Minyak motor & $\mathrm{Km}$ & 4.000 & 4.000 & 4.000 & 3.500 & 3.500 \\
\hline 10 & Peng. Minyak rem & $\mathrm{Km}$ & 8.000 & 8.000 & 8.000 & 12.000 & 12.000 \\
\hline 11 & Penggantian gemuk & $\mathrm{Km} / \mathrm{Kg}$ & 3.000 & 3.000 & 3.000 & 4.000 & 4.000 \\
\hline 12 & $\begin{array}{l}\text { Peng. } \\
\text { gardan }\end{array}$ & $\mathrm{Km}$ & 12.000 & 12.000 & 12.000 & 12.000 & 12.000 \\
\hline 13 & $\begin{array}{ll}\text { Peng. } & \text { Miny. } \\
\text { Persneleng } & \end{array}$ & $\mathrm{Km}$ & 12.000 & 12.000 & 12.000 & 12.000 & 12.000 \\
\hline 14 & $\begin{array}{l}\text { Hari jalan siap } \\
\text { operasi }\end{array}$ & $\mathrm{Hr} / \mathrm{Th}$ & 365 & 365 & 365 & 365 & 365 \\
\hline 15 & SO : GO & $\%$ & 80 & 80 & 80 & 80 & 80 \\
\hline 16 & Nilai residu & $\%$ & 20 & 20 & 20 & - & - \\
\hline
\end{tabular}

Sumber: SK 687/AJ.206/DRJD/2002

\subsubsection{Biaya Tidak Langsung (Undirect Cost)}

Menurut Warpani (2002), biaya tidak langsung adalah biaya yang tidak langsung dikenakan terhadap operasi tetapi menjadi bagian dari biaya pokok dan unit biaya, seperti biaya administrasi dan pengelolaan, biaya waktu kendaraan tak beroperasi, biaya hari libur, biaya kesehatan, bunga modal, dan lain-lain. Biaya tak langsung dapat dibagi menjadi biaya pokok dan biaya umum.

1. Biaya Pokok, adalah biaya dasar yang dikenakan antara lain pada lokasi, peralatan, dan prasarana seperti: a) yang dibayarkan tahunan asuransi, penyusutan, lisensi; b) biaya operasi gaji dan upah operator kendaraan, bahan bakar, dan pemeliharaan; c) lokakarya (workshop) yang dikenai bunga, upah, asuransi, dan lain-lain.

2. Biaya Umum, adalah biaya tak langsung yang timbul sebagai akibat dari kegiatan angkutan, seperti biaya administrasi atau biaya pengelolaan antara lain: prasarana, gaji direktur, gaji karyawan, peralatan kantor, biaya telapon, dan penyusutan nilai barang terutama alat produksi seperti kendaraan mengalami penyusutan nilai yang menjadi bagian dari beban biaya.

\subsubsection{Biaya Pokok Produksi Angkutan Umum}

Biaya pokok angkutan umum adalah besarnya biaya yang harus dikeluarkan oleh operator untuk dapat mengahsilkan satuan produksi pelayanan angkutan 
umum atau secara otomatis dapat dikatakan bahwa biaya pokok produksi angkutan umum adalah total biaya biaya operasi kendaraan per tahun dibagi dengan total produksi pelayanan per tahun. Persamaan dari biaya pokok produksi angkutan umum adalah:

$$
\mathrm{BPP}=\frac{\mathrm{BOK}}{\mathrm{TPP}}
$$

di mana:

$$
\begin{array}{ll}
\mathrm{BPP} & =\text { Biaya Pokok Produksi }(\mathrm{Rp} . / \mathrm{pnp}-\mathrm{Km}) \\
\mathrm{BOK} & =\text { Biaya Operasi Kendaraan }(\mathrm{Rp}) \\
\mathrm{TPP} & =\text { Total Produksi pelayanan }(\mathrm{pnp})
\end{array}
$$

\section{Metode Penelitian}

\subsection{Pengumpulan Data}

Data primer pada penelitian ini meliputi data yang diperoleh langsung dari lapangan seperti harga-harga satuan yakni harga bahan bakar minyak (bensin dan oli) dan harga ban. Selain data-data tersebut karena keterbatasan waktu dan biaya dalam penelitian ini maka data jumlah penumpang didapat dengan wawancara langsung dengan supir-supir atau pengusaha angkutan, bersamaan dengan pengambilan data pemakaian biaya-biaya operasi kendaraan seperti jumlah pemakaian bahan bakar, pemakaian ban, biaya perawatan, biaya administrasi kendaraan, dan biaya asuransi. Selain itu juga digunakan data kuesioner sebagai pembanding (komparasi) dari hitungan teknis. Kuesioner adalah sejumlah pertanyaan tertulis yang diajukan pada responden terdiri dari penumpang dan awak Bus dengan jumlah responden sebanyak 100 orang

\subsection{Analisis}

Penelitian diawali dengan identifikasi masalah, penetapan tujuan penelitian dan studi literatur. Pengumpulan data yang berupa data primer dan data sekunder. Setelah semua data terkumpul, langkah selanjutnya membagikan kuesioner kepada responden di wilayah kajian, setelah selesai dikumpulkan langkah selanjutnya dilakukan pengolahan/analisa data dengan bantuan Softwawre SPSS. (Statistical program for social science) versi 17.0. Setelah dilakukan pengolahan data maka tahap selanjutnya dilakukan uji validitas dan reliabilitas sesuai dengan ketentuan yang ada dan setelah dilakukan uji maka langkah selanjutnya dilakukan analisis statistik deskriptif yang bertujuan untuk menjelaskan latar belakang responden pengguna jasa angkutan umum bus trayek Lhokseumawe - Bireuen.

\section{Hasil dan Pembahasan}

\subsection{Biaya Pokok Angkutan Bus Kota}

\subsubsection{Karakteristik Kenderaan}

Penelitian ini dilakukan pada angkutan bus Cenderawasih dengan rute perjalanan Lhokseumawe-Bireuen. Adapun karakteristik kenderaan adalah termasuk kategori bus sedang yaitu kapasitas penumpang masih dibawah 50 penumpang dengan jenis pelayanan antar lintas kabupaten.

\subsubsection{Biaya Operasional Angkutan Bus per km}

Dalam penentuan tarif angkutan bus ditentukan oleh dua faktor yaitu biaya lansung dan biaya tidak langsung. 


\section{Biaya Langsung (Direct Cost)}

A. Biaya Tetap (Fixed Cost)

a. Biaya penyusutan, Harga beli sebesar Rp. 800.000.000,- dengan masa pakai kenderaaan sudah 5 tahun dan nilai penyusutan 20\%, sebesar Rp. 118,544 /bus-km

b. STNK/Pajak Iuran Kendaraan, Biaya Surat Tanda Nomor Kenderaan (STNK) sebesar Rp 350.000. Maka besaran faktor dari pajak iuran kenderaan Rp. 3,241 /bus-km.

c. Biaya Awak Bus, masing-masing 1 orang supir dan 1 orang kondektur. digaji sebesar Rp 2.600.000/bulan sehingga dalam setahun biaya keduanya sebesar Rp 62.400.000. Maka besar biaya yang dipengaruhi awak bus adalah Rp 577,901/bus-km.

B. Biaya Variabel (Variable Cost)

Perhitungan analisis biaya variabel cost meliputi :

a. Biaya Bahan Bakar Minyak (BBM), Kebutuhan bahan bakar setiap harinya 66 liter, untuk 3 trip perjalanan dengan harga Rp. 4.500 /liter maka biaya BBM sebesar Rp. 270.000. Besar biaya yang dipengaruhi bahan bakar minyak adalah Rp. 858,183 /bus-km.

b. Biaya Pengantian Ban, dilakukan setiap 4 bulan sekali dengan jumlah ban 6 buah ( 2 buah baru dan 4 buah vulkanisir), harga 2 buah ban baru sebesar Rp. 2.500.000 dan ban vulkanisir 4 buah sebesar Rp. 1.840.000. maka biaya pengantian ban adalah Rp. 124,199/bus-km.

c. Biaya Service Kecil, Service kecil dilakukan setiap $4000 \mathrm{Km}$ sekali, dimana pada service kecil ini hanya dilakukan untuk pengantian oli, gemuk dan minyak rem sebesar Rp. 260.000. Maka besar biaya yang dipengaruhi untuk pengantian ban adalah Rp. 65,625/bus-km.

d. Biaya Service Besar, Service besar dilakukan setiap $10.000 \mathrm{Km}$ sekali, dimana pada service besar ini dilakukan untuk pengantian oli, gemuk, minyak rem, oli garden, oli transmisi dan filter udara sebesar Rp. 618.000. Maka besar biaya yang dipengaruhi untuk service besar adalah Rp. 61,800 /bus-km.

e. Biaya Pemeriksaan, dilakukan setiap setahun sekali, sebesar Rp. 95,39 /bus-km.

f.Biaya Penambahan Oli, Penambahan oli dilakukan setiap hari dikarenakan oli pada mesin yang berkurang dan faktor yang mempengaruhi berkurangnya oli adalah karena ada kebocoran pada blok mesin, penambahan oli mesin 0,25 liter dengan jarak tempuh setiap harinya 336 $\mathrm{Km}$ dan mengeluarkan biaya sebesar Rp. 27.000 setiap harinya. Maka besar biaya yang dipengaruhi untuk biaya penambahan oli adalah $\mathrm{Rp}$. 19,504 /bus-km.

g. Biaya Cuci Bus, Pada umumnya mencuci bus merupakan kegiatan rutin yang harus dilakukan setiap hari membutuhkan biaya sebesar Rp. 20.000. Untuk pengoperasian selama 26 hari membutuhkan biaya sebesar Rp. 520.000. Maka besar biaya yang dipengaruhi biaya cuci bus adalah Rp. 57,790 /bus-km.

h. Biaya Restribusi Terminal, adalah biaya yang harus dibayar sebesar Rp. 9.000. Maka besar biaya yang dipengaruhi untuk biaya restribusi terminal adalah Rp. 26,006 /bus-km. 
i. Biaya Kir Kendaraan, Pada umumnya semua jenis mobil angkutan penumpang atau barang harus memiliki buku kir kendaraan biaya untuk kir kendaraan sebesar Rp. 75.000 setiap enam bulan sekali dan untuk satu tahun biaya yang dikeluarkan adalah sebesar Rp. 150.000, kir kendaraan dilakukan setahun dua kali. Maka besar biaya yang dipengaruhi untuk biaya kir kendaraan adalah Rp. 1,389 /bus-km.

j. Biaya Asuransi, kendaraan angkutan umum bus CV. Cendrawasih tidak mengasuransikan kendaraanya, yang disuransikan hanyalah asuransi jiwa setiap tahunnya sebesar Rp. 450.000. Maka besar biaya yang dipengaruhi untuk biaya asuransi kendaraan adalah Rp. 4,168 /bus-km.

\section{Biaya Tidak Lansung (Undirect Cost)}

Pengeluaran biaya pegawai selain awak bus sebesar Rp. 43.200.000,- pertahun. Besar kebutuhan biaya pengelolaan adalah sebesar Rp. 24.900.000,- yaitu kumulatif dari rincian kebutuhan biaya seperti biaya penyusutan bangunan kantor, penyusutan sarana bengkel, listrik dan air, dan sebagainya. Berdasarkan dari masing-masing pengeluaran biaya diperoleh total kebutuhan biaya sebesar Rp.68.100.000,00. Biaya ini dipengaruhi oleh jumlah bus perusahaan dan juga jumlah bus yang beroperasi. Dari 80 armada yang beroperasi dalam trayek sebanyak 35 armada sehingga diperoleh biaya tidak lansung untuk satu bus dalam setahun sebesar Rp. 1.945.714,--

\section{Biaya pokok per bus-km}

Biaya pokok yang dikeluarkan dari biaya langsung dan tidak langsung, maka besar biaya pokok per bus-km sebesar Rp. 2.031,760/bus-km.

\section{Biaya pokok per penumpang-km}

Besarnya biaya pokok per penumpang bus-km ditentukan oleh kapasitas penumpang dan dihitung berdasarkan tempat duduk. Semakin besar kapasitas bus akan mempunyai jumlah kapasitas penumpang bertambah maka semakin besar biaya pokok yang dikeluarkan.

\section{Posisi biaya pada berbagai tingkat faktor muat}

Tingkat faktor muat adalah jumlah penumpang yang terjadi selama beroperasi satu kali perjalanan, dimana dihitung penumpang naik dan penumpang turun. Faktor muat ini sangat berpengaruh dalam penentuan tarif sebuah angkutan umum karena besar atau kecilnya biaya tergantung dari faktor muat penumpang itu sendiri. Tingkat faktor muat sebesar $45 \%$ dengan kebutuhan biaya untuk setiap penumpang sebesar Rp163.245 /pnp-km.

\section{Rekapitulasi Biaya Pokok :}

Rekapitulasi biaya pokok untuk kebutuan bus-km sebesar Rp. 2.031,760 /bus$\mathrm{km}$ dan biaya pokok kebutuhan penumpang Rp. 156,289/penumpang-km.

\section{Break Event Point}

Break event point adalah titik pulang pokok di mana biaya yang diterima sama dengan biaya yang dikeluarkan atau 0 (nol). Biaya break event point sebesar Rp. 8.752,20 /pnp dan tarif saat ini dilapangan adalah sebesar Rp. 
10.000 /pnp maka pengusaha atau pemilik angkutan umum masih mampu mengoperasikan kendaraannya dan masih dapat menutupi biaya yang dikeluarkan untuk pengoperasian angkutan umum.

\subsection{Analisa data kuesioner}

\subsubsection{Uji validitas dan reliabilitas data}

Uji validitas dengan menggunakan 100 orang sampel pada taraf signifikan $5 \%$ dengan nilai $\mathrm{r}$ tabel product moment 0.195 maka semua pertanyaan dinyatakan valid, memenuhi kriteria sesuai indeks korelasi dan nilai reliabilitas seperti yang diperlihatkan pada Tabel 2

Tabel 2 Item-Total Statistics

\begin{tabular}{|c|c|c|c|}
\hline Pertanyaan & Corrected Item-Total & Cronbach's Alpha if Item & r tabel product moment \\
\hline P.1 & -0.202 & 0.666 & 0.195 \\
\hline P.2 & 0.773 & 0.249 & 0.195 \\
\hline P.3 & -0.091 & 0.597 & 0.195 \\
\hline P.4 & 0.472 & 0.440 & 0.195 \\
\hline P.5 & 0.450 & 0.529 & 0.195 \\
\hline P.6 & 0.761 & 0.312 & 0.195 \\
\hline P.7 & 0.450 & 0.523 & 0.195 \\
\hline P.8 & 0.438 & 0.525 & 0.195 \\
\hline P.9 & -0.575 & 0.631 & 0.195 \\
\hline
\end{tabular}

Dari hasil Uji Reliabilitas didapatkan nilai r cronbach's alpha 0,560 lebih besar dibandingkan dengan nilai $\mathrm{r}$ tabel product moment 0.195 maka semua pertanyaan diatas dinyatakan reliable seperti diperlihatkan pada tabel 4

\section{Tabel 4 Reliability Statistics}

\begin{tabular}{|c|c|c|}
\hline Cronbach's Alpha & N of Items & $\mathrm{r}$ tabel product moment \\
\hline 0,560 & 9 & 0.195 \\
\hline
\end{tabular}

\subsubsection{Pengujian Hipotesis}

Prosedur pengujian hipotesis yang dilakukan dengan tiga tahap yaitu tingkat kepercayaan, derajat kebebasan dan pengambilan keputusan. Berdasarkan hasil dari SPSS versi 17.0 dengan menganalisis data lanjutan menggunakan metode One Sample Test diperoleh nilai seperti yang di perlihatkan pada Tabel 5.

Tabel 5 Hasil uji hipotesis

\begin{tabular}{|c|c|c|c|c|c|}
\hline Pertanyaan & Uji t & t tabel & $\begin{array}{c}\text { Degree of } \\
\text { Freedom }(\mathrm{df})\end{array}$ & $\begin{array}{c}\text { Tingkat } \\
\text { kepercayaan }\end{array}$ & Hipotesis \\
\hline P1 & 14,866 & 1,9840 & 99 & $95 \%$ & Diterima \\
\hline P2 & 20,142 & 1,9840 & 99 & $95 \%$ & Diterima \\
\hline P3 & 32,798 & 1,9840 & 99 & $95 \%$ & Diterima \\
\hline P4 & 25,936 & 1,9840 & 99 & $95 \%$ & Diterima \\
\hline P5 & 53,323 & 1,9840 & 99 & $95 \%$ & Diterima \\
\hline P6 & 21,704 & 1,9840 & 99 & $95 \%$ & Diterima \\
\hline P7 & 33,592 & 1,9840 & 99 & $95 \%$ & Diterima \\
\hline P8 & 34,420 & 1,9840 & 99 & $95 \%$ & Diterima \\
\hline P9 & 28,162 & 1,9840 & 99 & $95 \%$ & Diterima \\
\hline
\end{tabular}




\subsection{Pembahasan}

Besaran tarif menurut aturan DLAJJR diperoleh Rp. 8.718,66 atau disebut biaya pokok. Apabila dilihat dari biaya pulang pokok atau biaya modal diperoleh Rp. 8.752,20 sedangkan tarif yang berlaku saat ini sebesar Rp. 10.000,00. selisih harga atau dinaikkan sebesar Rp. 1.247,8. Berdasarkan berlakunya tarif sekarang maka pengusaha bus sudah tepat dalam mengeluarkan besaran tarif walaupun tidak menggunakan acuan atau berdasarkan asumsi saja atau dengan kata lain pengeluaran kotor dalam sekali perjalanan ditambah keuntungan. Tarif optimum seharusnya bisa diberlakukan sebesar Rp. 8.752,20 dan biaya tersebut adalah pengeluaran keseluruhan biaya langsung dan tidak langsung.

Untuk menjawab dari hipotesis yang akan dicapai diperoleh beberapa hasil sebagai berikut:

1. Hipotesa 1, bahwa tarif yang telah diberlakukan saat ini sebesar Rp. 10.000,00. Hal ini menunjukkan masih sesuai karena besaran angka diatas tarif penelitian diambil berdasarkan cara DLLAJ.

2. Hipotesa 2, menyatakan bahwa pengguna angkutan bus menikmati perjalanan dengan layak dan nyaman. Hal ini ditunjukkan dari hasil data semua penumpang atau $100 \%$ mengatakan bus layak dan nyaman untuk ditumpangi.

3. Hipotesa 3, menyatakan bahwa penumpang angkutan bus CV. Cendrawasih masih aman ditumpangi dikarenakan rata-rata kuantitas penumpang yang ada sebesar $45 \%$ dari kursi yang tersedia sehingga dapat dikatakan masih banyak tempat duduk yang kosong, tidak berdesakkan dan tidak menimbulkan penjambretan.

\section{Kesimpulan dan Saran}

\subsection{Kesimpulan}

Berdasarkan hasil survey dan analisa data yang dilakukan dalam penelitian ini, maka dapat diambil kesimpulan sebagai berikut :

1. Angkutan umum bus CV. Cendrawasih yang melayani rute perjalanan atau trayek Lhokseumawe - Bireuen memberikan pelayanan yang relatif baik walaupun jumlah armada yang beroperasi hanya 35 unit.

2. Faktor pembebanan (load factor) rata-rata angkutan antar kota Trayek Lhokseumawe - Bireuen adalah sebesar $45 \%$ dengan jumlah rata penumpang per trip adalah 13 penumpang.

3. Besarnya biaya operasi kendaraan dihitung berdasarkan biaya langsung dan biaya tidak langsung di mana biaya langsung sebesar Rp. 2.013,740 /bus-km. dan biaya tidak langsung Rp. 18,020 / bus-km.

4. Besarnya biaya operasi kendaraan rata-rata sebesar Rp. 156,289/pnp/km.

5. Besarnya tarif dihitung berdasarkan biaya operasi kendaraan (BOK) dan jumlah penumpang rata-rata/trip sebesar Rp. 8.752,20 /penumpang.

6. Tarif yang telah diberlakukan selama ini adalah sebesar Rp. 10.000,00. Hal ini menunjukkan tarif masih sesuai

7. Bus CV. Cendrawasih layak dan nyaman. Hal ini ditunjukkan dari hasil data semua penumpang atau $100 \%$ mengatakan bus CV. Cendrawasih masih dikatakan layak dan nyaman karenakan rata-rata penumpang yang ada sebesar $45 \%$ dari kursi yang tersedia sehingga dapat dikatakan masih banyak tempat duduk yang kosong 


\subsection{Saran}

Dari uraian diatas dengan merujuk pada pembahasan dan hasil penelitian dikemukakan saran-saran sebagai berikut :

1. Perlunya kajian ulang dari pemerintah daerah terhadap besaran tarif yang ditetapkan, mengingat kenaikan harga-harga yang terus terjadi.

2. Diharapkan perusahaan angkutan umum Bus CV. Cendrawasih untuk menerapkan sistem pengelolaan secara menyeluruh, dalam arti perusahaan bukan hanya sebagai biro jasa tetapi juga mengelola seluruh biaya yang dikeluarkan yang berhubungan dengan pengoperasian kendaraan, sehingga keuntungan dapat sama-sama dinikmati oleh perusahaan maupun oleh pemilik kendaraan dan sementara kesejahteraan pengemudi juga terjamin.

3. Kurangnya disiplin dari pengemudi maupun penumpang angkutan umum, terlihat dari perilaku pengemudi berhenti disembarang tempat untuk menaikkan dan menurunkan penumpang, oleh sebab itu perlu adanya diadakan penyuluhan ataupun seminar-seminar yang berkaitan dengan keadaan pemakaian jalan dan jasa angkutan umum.

\section{Daftar Kepustakaan}

1. Anonim, 2002, Pedoman Teknis Penyelengaraan Angkutan Penumpang Umum di Wilayah Perkotaan dalam Trayek Tetap dan Teratur, Direktorat Jendral Perhubungan Darat, Departemen Perhubungan, Jakarta

2. Fahrizal, 2008, Studi Angkutan Umum di kabupaten Bireuen (Angkutan Kota Trayek 02 Jurusan Matang Glumpang Dua-Samalanga), Unimal, Lhokseumawe

3. Fidel Miro S.E, MSTr, 2005, Perencanaan Transportasi, Erlangga, Jakarta,

4. Tamin, Z, Ofyar, 2000, Perencanaan dan Pemodelan Transportasi, ITB,Bandung

5. Sakti Adji Adisasmita, 2011, Perencanaan Pembangunan Transportasi, Graha Ilmu, Yogyakarta

6. Salim, H.A. Abbas, 1993, Manajemen Transfortasi, PT. Raja Grafindo Persada, Jakarta

7. Siregar, Muchtarudin, 1995, Tarif Angkutan, Departernen Perhubungan

8. Sri Widari, 2010, Analisis Tarif Angkutan Pedesaan Berdsarkan Biaya Operasi Kendaraan (BOK). (Studi Kasus Kabupaten Gayo Lues Nanggroe Aceh Darussalam). Universitas Sumatera Utara (USU), Medan

9. Suwarjoko P, Warpani, 2002, Penggelolaan Jalan dan Angkutan Jadan, ITB, Bandung

10. Warpani, Suwarjoko, 1990, Merencanakan Sistem Perangkutan, ITB, Bandung 